\title{
HUBUNGAN KARAKTERISTIK INDIVIDU DENGAN DISIPLIN KERJA DI PUSKESMAS AJANG KABUPATEN SUKAMARA
}

\author{
${ }^{1}$ Rahaju Ningtyas,S.Kp.,M.Kep \\ ${ }^{1}$ STIKes Borneo Cendekia Medika Pangkalan Bun \\ 1rahaju.ningtyas01@gmail.com
}

\begin{abstract}
ABSTRAK
Kepuasan pasien terhadap pelayanan kesehatan yang berkualitas dianggap masyarakat sebagai profesionalisme kerja oleh seorang tenaga kesehatan. Tuntutan masyarakat akan terpenuhi jika pemberi layanan memiliki propesionalisme yang tinggi dan mampu mempertahankan citra dan kinerja yang memenuhi standar pelayanan. Disiplin kerja juga mempunyai kontribusi terhadap kualitas pelayanan keperawatan yang pada akhirnya berdampak pada produktivitas kerjanya.Tanpa ada dukungan disiplin yang tinggi dari karyawan, perusahaan atau organisasi sulit untuk mewujudkan tujuan yang ingin dicapai. Karakteristik individu merupakan bagaian dari faktor demografi yang dapat mempengaruhi perilaku individu, termasuk perilaku disiplin dalam bekerja yang terdiri dari umur, jenis kelamin, tingkat pendidikan, lama kerja, dan status perkawinan.Tujuan dari penelitian ini adalah menganalisa hubungan antara karakteristik individu dengan tingkat disiplin kerja di Puskesmas Ajang Kabupaten Sukamara. Penelitian ini menggunakan metode deskriptif korelasi dengan pendekatan cross sectional.Populasi didalam penelitian ini adalah seluruh karyawan Puskesmas Ajang Kabupaten Sukamara dengan teknik sampling yang digunakan adalah total sampling. Hasil penelitian yang didapatkan adalah tidak ada hubungan antara usia, jenis kelamin, pendidikan dan status pernikahan terhadap tingkat disiplin kerja karyawan $(p>0.05)$. Saran dari peneliti adalah disiplin karyawan di Puskesmas tetap dipertahankan walaupun dengan jarak tempat tinggal karyawan ke Puskesmas yang tidak dekat, tetapi dengan menjaga berangkat tetap lebih awal sehingga tidak melanggar disiplin.
\end{abstract}

\section{Kata Kunci : Karakteristik Individu, Disiplin Kerja}

\section{RELATIONSHIP OF INDIVIDUAL CHARACTERISTICS AND WORKING DISCIPLINE IN AJANG PUSKESMAS SUKAMARA DISTRICT}

\begin{abstract}
Patient satisfaction with quality health services is considered by the community as professional work by a health worker. Community demands will be met if service providers have high professionalism and are able to maintain an image and performance that meets service standards. Work discipline also contributes to the quality of nursing services, which in turn has an impact on work productivity. Without high discipline support from employees, companies or organizations it is difficult to realize the goals to be achieved. Individual characteristics are part of demographic factors that can affect individual behavior, including disciplinary
\end{abstract}


behavior at work consisting of age, sex, education level, length of work, and marital status. The purpose of this study is to analyze the relationship between individual characteristics and the level of work discipline at the Ajang Health Center in Sukamara Regency. This study used a descriptive correlation method with a cross sectional approach. The population in this study was all employees of the Ajang Community Health Center in Sukamara with the sampling technique used was total sampling. The results obtained were that there was no relationship between age, sex, education and marital status on the level of employee work discipline ( $p>0.05$ ). The suggestion from the researcher is that employee discipline at the Puskesmas is maintained even though the distance of the employee's residence to the Puskesmas is not close, but by keeping leaving early so that it does not violate discipline.

Keywords: Individual Characteristics, Work Discipline

\section{PENDAHULUAN}

Terbukanya pasar bebas berakibat tingginya kompetisi di sektor kesehatan dan kompleksnya permasalahan sehingga unit-unit pelayanan kesehatan belomba-lomba untuk meningkatkan kualitas pelayanan dan produktifitasnya. Pengaruh terbesar akibat era globalisasi tersebut adalah perkembangan pelayanan kesehatan. Pelayanan yang berkualitas merupakan pelayanan yang dapat memuaskan masyarakat yang mendapatkan jasa pelayanan kesehatan yang sesuai dengan tingkat kepuasan serta penyelenggarannya sesuai dengan standar dan kode etik profesi yang telah ditetapkan.

Organisasi pelayanan kesehatan harus membenahi semua aspek yang berhubungan dengan peningkatan kualitas pelayanan yang diberikan termasuk pembenahan terhadap sumberdaya manusianya. Selain itu kualitas pelayanan kesehatan yang dihasilkan oleh Puskesmas sangat dipengaruhi oleh kinerja pemberi pelayanan kesehatan itu sendiri, terbentuknya kinerja yang baik dapat dapat terlihat dengan hasil kerjanya dan kedisplinan para karyawannya sehingga akan dapat meningkatkan motivasi serta produktivitas yang dapat berpengaruh terhadap laju roda organisasi (Robins, 2006). Pada kenyataannya membentuk kinerja dan kedisiplinan para karyawan tidak mudah. Adapun faktor yang mempengaruhi kualitas pelayanan kesehatan di institusi pelayanan kesehatan diantaranya keterbatasan sumber daya manusia (SDM) baik dari segi jumlah, juga masih terbatasnya SDM yang menerapkan nilai-nilai moral dan etika profesi. Kurangnya nilai-nilai moral dan etika sumberdaya manusia akan berdampak terhadap disiplin kerjanya.

Di Indonesia, tingkat kediplinan karyawan khususnya pegawai negeri masih kurang, sekitar $45 \%$ pegawai negeri kurang mentaati peraturanperarturan kepegawaian yang telah ditetapkan, terutama tentang jam 
datang dan pulang kerja. Perilaku disiplin yang ditunjukan oleh karyawan dapat menguntungkan organisasi khususnya yang berorientasi kepada produk jasa pelayanan yang dihasilkan (Mirvis \& Lamber, 1997 dalam Anastasia, 2000). Menurut Gibson (1996) variabel yang mempengaruhi perilaku dan prestasi yaitu (1) variabel individu yang terdiri dari kemampuan dan ketrampilan (mental, fisik, dan latar belakang keluarga, tingkat sosial, pengalaman), demografi (umur, asal usul, jenis kelamin), dan (2) variabel organisasi yang terdiri dari sumber daya, kepemimpinan, imbalan, struktur dan desain pekerjaan, serta (3) variabel psikologi yang terdiri dari persepsi, sikap, kepribadian, belajar, motivasi.

\section{METODE PENELITIAN}

Penelitian ini menggunakan metode deskriptif korelasi dengan pendekatan cross sectional.Populasi didalam penelitian ini adalah seluruh karyawan Puskesmas Ajang Kabupaten Sukamara dengan teknik sampling yang digunakan adalah total sampling. Dalam penelitian ini yang menjadi variable independen adalah karakteristik karakteristik individu sebagai variabel independen dengan sub variabelnya adalah variabel umur, jenis kelamin, pendidikan, status perkawinan dan lama kerja, variabel dependen pada penelitian ini adalah tingkat disiplin kerja karyawan Puskesmas Ajang.

\section{HASIL PENELITIAN}

a. Data karakteristik individu perawat (umur, jenis kelamin, pendidikan, status perkawinan) di Puskesmas Ajang.

Ssebagian besar umur Responden di Puskesmas Ajang berumur 25 45 tahun sebanyak $60 \quad \% \quad$ (12 responden), sebagian besar jenis kelamin responden di Puskesmas Ajang berjenis kelamin perempuan sebanyak $60 \%$ (12 responden). Sebagian besar pendidikan Responden di Puskesmas Kedewan Kabupaten Bojonegoro berpendidikan tinggi sebanyak $75 \%$ (15 responden). Hampir seluruh status menikah responden di Puskesmas Ajang berstatus menikah sebanyak $90 \%$ (18 responden). Hampir seluruh tingkat kedisiplinan kerja karyawan responden di Puskesmas Ajang memiliki tingkat disiplin sebanyak $95 \%$ (19 responden).

b. Hubungan antara karakteristik individu dengan tingkat disiplin kerja Karyawan di Puskesmas Ajang.

1. Umur

Hasil penelitian menunjukan terdapat nilai $x^{2}=1.579$ dengan nilai $p$ value $=0,209 . p$ value $<0.05$ sehingga dapat diambil kesimpulan bahwa tidak ada hubungan umur dengan tingkat disiplin kerja Karyawan di Puskesmas Ajang 
2. Jenis Kelamin

Hasil analisis didapatkan nilai $x^{2}=1.579$ dengan nilai $p$ value $=0,209$.

$p$ value $>0.05$ sehingga dapat diambil kesimpulan bahwa tidak ada hubungan jenis kelamin dengan tingkat disiplin kerja Karyawan di Puskesmas Ajang.

3. Pendidikan

Hasil analisis didapatkan nilai $x^{2}=0,351$ dengan nilai $p$ value $=0,554$.

$p$ value $>\alpha(\alpha=0.05)$ sehingga dapat diambil kesimpulan bahwa tidak ada hubungan tingkat pendidikan dengan tingkat disiplin kerja Karyawan di Puskesmas Ajang.

4. Status menikah

Hasil analisis didapatkan nilai $x^{2}=0,117$ dengan nilai $p$ value $=0,732$. $p$ value $>\alpha(\alpha=0.05)$ sehingga dapat diambil kesimpulan bahwa tidak ada hubungan status menikah dengan tingkat disiplin kerja Karyawan di Puskesmas Ajang.

\section{PEMBAHASAN}

1. Hubungan umur dengan tingkat disiplin kerja Karyawan di Puskesmas Ajang Kabupaten Sukamara.

Dari tabel 5.6 dapat diamati lebih dari separuh karyawan di Puskesmas Ajang Kabupaten
Sukamara disiplin dengan usia 25

- 45 tahun sebesar 63,2 \% ( 12 karyawan ).

Pada tabel 5.7 terdapat nilai chi square sebesar 1.579 dengan nilai $P$ value sebesar 0,209. $P$ Value lebih besar dari $\alpha$ sehingga dapat diambil kesimpulan bahwa tidak ada hubungan umur dengan tingkat disiplin kerja Karyawan di Puskesmas Ajang Kabupaten Sukamara.

Di usia yang matang dan produktif sudah selayaknya karyawan sadar akan hak dan kewajiban yang harus dilakukannya, sehingga sadar untuk memenuhinya sebagai manusia yang bertanggung jawab. Hal yang sama disampaikan oleh Hasibuan (2003), bahwa Disiplin adalah kesadaran dan kesediaan seseorang, menaati semua peraturan perusahaan dan normanorma sosial yang berlaku.

2. Hubungan jenis kelamin dengan tingkat disiplin kerja Karyawan di Puskesmas Ajang Kabupaten Sukamara.

Dari tabel 5.8 dapat diamati lebih dari separuh karyawan di Puskesmas Ajang Kabupaten Sukamara disiplin dengan jenis kelamin perempuan sebesar 63,2 $\%$ (12 karyawan).

Pada tabel 5.9 terdapat nilai chi square sebesar 1.579 dengan nilai $\mathrm{P}$ value sebesar 0,209. $\mathrm{P}$ Value lebih besar dari $\alpha$ sehingga dapat diambil kesimpulan bahwa tidak ada hubungan jenis kelamin dengan tingkat disiplin kerja 
Karyawan di Puskesmas Ajang Kabupaten Sukamara.

Disiplinnya seorang karyawan tidak dipengaruhi oleh gender, hak dan kewajiban melekat pada setiap karyawan dan hal tersebut sudah dengan alam sadar untuk melaksanakan sesuai dengan norma yang berlaku. Hal tersebut di pertegas oleh Menurut Robbins (2001), norma berarti standar perilaku yang dapat diterima, yang digunakan bersama oleh anggota kelompok, untuk memberitahukan tentang apa yang seharusnya dan tidak seharusnya. Hal ini diperjelas oleh Jacobs Evereet (1988, dalam Ilyas, 2003), yang menyebutkan bahwa, norma sebagai wahana mental kelompok yang berkaitan dengan apa yang harus dilakukan dan berpengaruh terhadap perilaku internal individu.

3. Hubungan pendidikan dengan tingkat disiplin kerja Karyawan di Puskesmas Ajang Kabupaten Sukamara

Dari tabel 5.10 dapat diamati sebagian besar karyawan di Puskesmas Ajang Kabupaten Sukamara disiplin dengan pendidikan tinggi sebesar $73,7 \%$ (14 karyawan).

Pada tabel 5.11 terdapat nilai chi square sebesar 0,351 dengan nilai $\mathrm{P}$ value sebesar 0,554. $\mathrm{P}$ Value lebih besar dari $\alpha$ sehingga dapat diambil kesimpulan bahwa tidak ada hubungan tingkat pendidikan dengan tingkat disiplin kerja
Karyawan di Puskesmas Ajang Kabupaten Sukamara.

Semua karyawan dari berbagai tingkat pendidikan wajib melaksanakan tugas dan kewajiban dengan disiplin sesuai dengan uraian tugas jabatan. Manajemen berhasil melaksanakan peran dan fungsinya dalam hal kedisiplinan tanpa melihat tingkat pendidikannya. Hasibuan (2003) menjelaskan terdapat faktor yang mempengaruhi kediplinan kerja karyawan antara lain karyawan yang memiliki kemampuan terhadap pekerjaannya akan bekerja sesuai dengan kemampuan yang dimilikinya, adanya pimpinan hendaknya menjadi contoh yang baik, disiplin tinggi, jujur dan sesuai antara kata-kata dengan perbuatan. Dengan keteladanan dan kedisiplinan pimpinan yang tinggi maka bawahanpun akan mengikutinya. Begitu juga sebaliknya.

4. Hubungan status menikah dengan tingkat disiplin kerja Karyawan di Puskesmas Ajang Kabupaten Sukamara.

Dari tabel 5.12 dapat diamati sebagian besar karyawan di Puskesmas Ajang Kabupaten Sukamara disiplin dengan status menikah sebesar $89,5 \%$ ( 17 karyawan ).

Pada tabel 5.13 terdapat nilai chi square sebesar 0,117 dengan nilai $P$ value sebesar 0,732. $P$ Value lebih besar dari $\alpha$ sehingga dapat diambil kesimpulan bahwa tidak ada hubungan status menikah 


\begin{abstract}
dengan tingkat disiplin kerja Karyawan di Puskesmas Ajang Kabupaten Sukamara.

Karyawan dengan status pernikahan apapun memiliki tanggung jawab yang sama , terlebih perawat yang mengelola asuhan kepada pasien. Kedudukan karyawan sudah selayaknya bersifat general tanpa memandang status pernikahanHasibuan (2003) menjelaskan terdapat faktor yang mempengaruhi kediplinan kerja karyawan antara lain pimpinan menciptakan suasana hubungan kemanusiaan dalam lingkungan kerja yang serasi dan mengikat,baik dengan atasan maupun bawahan antar semua karyawan.
\end{abstract}

\section{KESIMPULAN DAN SARAN}

1. Kesimpulan

Tidak ada hubungan antara karakteristik individu (umur, jenis kelamin, tingkat pendidikan dan status menikah) dengan tingkat disiplin kerja karyawan di Puskesmas Ajang Kabupaten Sukamara.

2. Saran

Pihak manajemen Puskesmas tetap membina karyawan dengan tetap terus memotivasi karyawan untuk tetap menjalankan aturan yang berlaku. Disiplin karyawan di Puskesmas tetap dipertahankan walaupun dengan jarak tempat tinggal karyawan ke Puskesmas yang tidak dekat, tetapi dengan menjaga berangkat tetap lebih awal sehingga tidak melanggar disiplin.

\section{DAFTAR PUSTAKA}

Azwar, Azrul. (1996). Menjaga Mutu Pelayanan Kesehatan. Jakarta: Sinar Harapan.

Aditama, T.Y. (2003). Manajemen Administrasi Rumah Sakit, Edisi Kedua, Jakarta: Penerbit Universitas Indonrsia (UI-Press).

Ayu Kartika Sari Dewi. (2015) Determinasi Karakteristik Individu, Disiplin Kerja Dan Motivasi Terhadap Kinerja Karyawan (Studi Empiris Pada Koperasi Simpan Pinjam Arta Niaga Banyuwangi), E-Journal Universitas Muhammadiyah Jember.

Efrizansyah, 2013) Pengaruh Disiplin Kerja, Lingkungan Kerja Dan Karakteristik Individu Terhadap Kinerja Pegawai Pada Upt Pendidikan Kecamatan Karang Intan Kabupaten Banjar, Kindai Volume 9 Nomor 3, Juli September 2013.

Gibson. James, L., et . all. (1998). Organisasi Perilaku, Struktur, Proses, Alih bahasa: Djarkasih. Jakarta : Erlangga.

Hasibuan (2003). Manajemen Sumber Daya Manusia. Edisi Revisi, Bumi Aksara, Jakarta

Handoko, T Hani. (2001). Manajemen Personalia dan Sumberdaya Manusia, Edisi Kedua. BPFE, Yogyakarta.

Ilyas.Y. (2002). Kinerja Teori Penilaian \& Penelitian. Pusat Kajian Ekonomi Kesehatan FKM UI,Depok

J. H. Pusungunaung.(2015). Hubungan Antara Disiplin Kerja Dan Karakteristik Individu 
Dengan Produktivitas Kerja Perawat Di Puskesmas Kota Tomohon, E-Journal Universitas Samratulangi, volume 5 No 6

Notoatmodjo, S,(2003). Pendidikan dan Perilaku Kesehatan. Jakarta: Penerbit Rineka Cipta

Mangkunegara, AA Anwar Prabu, (2011). Manajemen Sumber Daya Manusia. Perusahaan, PT Remaja Rosdakarya, bandung.

Prasojo Eko. (2006). Aditya perdana, Norr HIqmah, Kinerja Pelayanan Publik: Persepsi Masyarakat terhadap Kinerja, Keterlibtan dan Partisipasi dalam Pelayanan Pendidikan, Kesehatan dan Kependudukan. Jakarta:Yappika.

Robbins, Stephen P. (2006). Perilaku Organisasi. Edisi kesepuluh. Jakarta: PT Indeks Kelompok Gramedia

Rasmun .(2004). Stres, Koping dan adaptasi. Jakarta:Sagug Seto

Siagian, Sondang P. (2005). Manajemen Abad 21. Bumi Aksara, Jakarta.

Siagian, Sondang. P. (1982). Organisasi, Kepemimpinan dan Perilaku Organisasi. Jakarta : PT gunung Agung Siyo, $\mathrm{H}$. Soekirman, K. Purwandari, H. (2008). Wong Jawa di Sumatera. Medan : Pujakesuma.

Triguno, (2004). Budaya Kerja. Menciptakan Lingkungan Yang Kondusif Untuk meningkatkan Produktivitas Kerja, Edisi 6, PT. Golden Trayon Press, Jakarta.

Zainul Hidayat, MM \& Muchamad Taufiq, MH. (2012). Pengaruh Lingkungan Kerja dan Disiplin Kerja serta Motivasi Kerja Terhadap Kinerja Karyawan Perusahaan Daerah Air Minum (PDAM) Kabupaten Lumajang,
Jurnal WIGA Vol. 2 No. 1, Maret 2012 ISSN NO 2088-0944 